\title{
\#USES \\ Vegetation Recovery after Fire in the Klamath-Siskiyou Region, Southern Oregon
}

In July 2002, lightning strikes started five forest fires that merged into one massive wildfire in the KlamathSiskiyou Ecoregion of southern Oregon. Aided by drought, severe weather conditions, dry fuels, and steep topography, the fire grew to more than 200,000 hectares of mostly public forest land. Known as the Biscuit Fire, it was Oregon's largest forest fire in more than 130 years and one of the largest wildfires on record in the United States. Discussions centered around why such a massive fire was happening, how large would it become, who was keeping communities and homes safe, and what would be the final economic and ecological outcome. Weeks later when the fire was out, conversations turned to other questions, including what, if anything, should happen for forest recovery.
A fire regime is the pattern, frequency, and intensity of the fires that prevail in an area. The Klamath-Siskiyou Ecoregion has a mixed-severity fire regime. This category includes fires that cause either selective mortality in the dominant vegetation, or burn in patches of various severity, ranging from understory fires to complete destruction of vegetation. The burned landscape after the Biscuit Fire was a mosaic of live and dead trees in variable-sized patches. The patterns of the mosaic were further defined by a previous fire that burned the same area 15 years earlier - the Silver Fire of 1987.

Following fires, land managers typically make decisions about forest restoration, such as whether to conduct logging, plant vegetation, or manage erosion; and if any treatments are applied, they need to decide how large an area to treat and how quickly. Complex factors also are evaluated, including fire histories, previously applied management actions, characteristics of soils and hydrology, wildlife living in the forest, societal goals for the forested area, proximity of homes and businesses, proximity and condition of other forests, and anticipated future climates. Often, re-growth of vegetation, which is called regeneration, is a top priority.

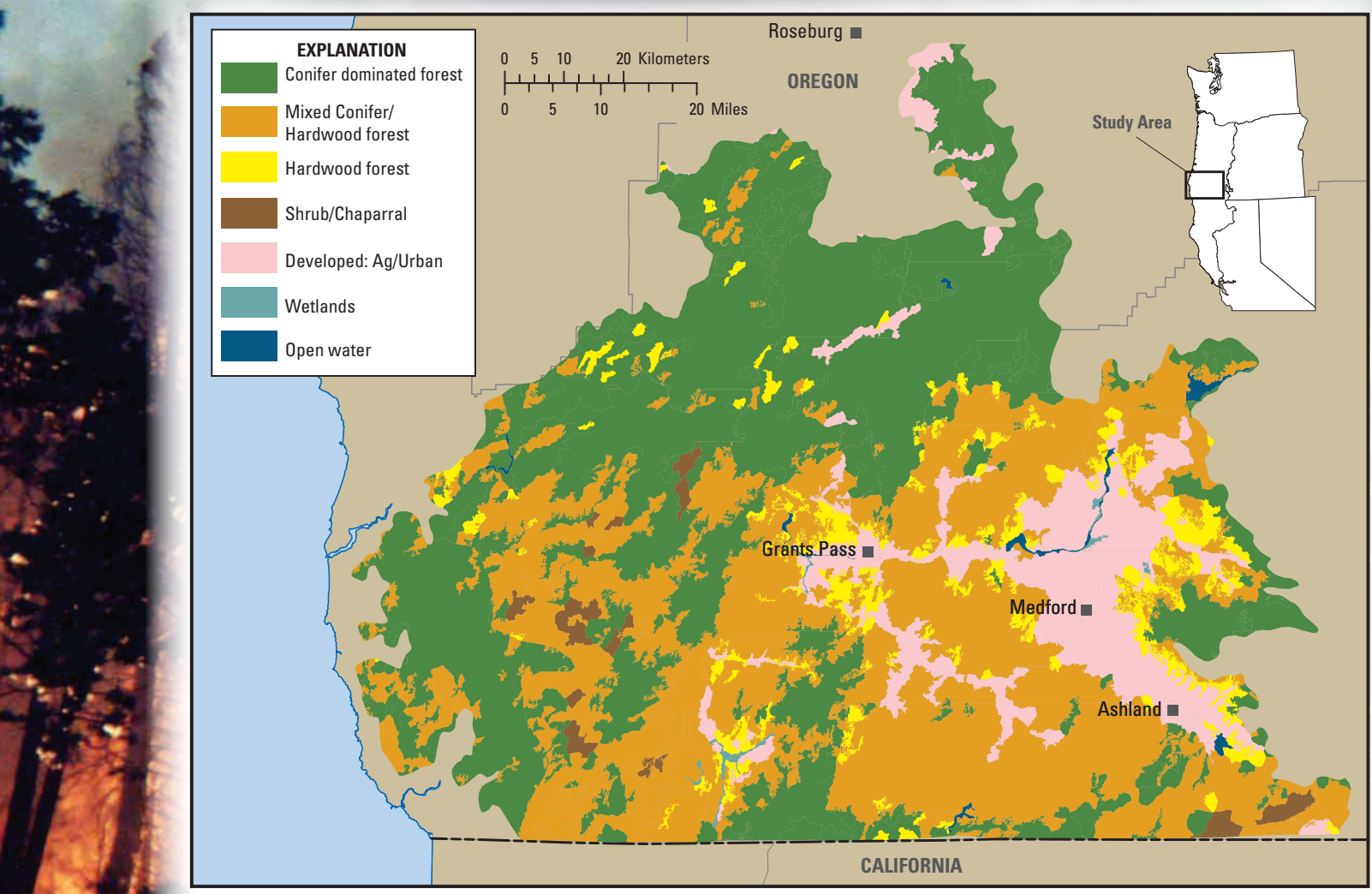


the combined influences of altitude and the amount of heat an area potentially receives, known as heat load, affect conifer regeneration more than competitive interactions with other plant species. In a practical sense, this means that it is more difficult to achieve regeneration on low-altitude, steep, southern-facing sites than on moist, high-altitude sites. Areas dominated by pines naturally tend to be in some of the driest areas, and natural pine regeneration can be especially difficult to achieve. In fact, in managed areas where ponderosa pine have been planted, pine densities are frequently greater than pine densities in naturally regenerating unmanaged areas.

\section{Seedling Survival and Regeneration Patterns}

Seedling survival is as important to forest regeneration as the dispersal and germination of seeds. Many factors influence survival, including soils, precipitation, temperature, animal predation, and site disturbance. Probably none of these factors is as debated as the logging of fire-damaged trees, a practice known as salvage logging. Research provides some insights regarding effects on seedlings. For example, when researchers looked at the areas logged 2 years after the Biscuit Fire, they found conifer seedlings much less abundant in salvage-logged areas than in unlogged areas. Possibly this was because seedlings were killed by site disturbance associated with logging. If early loss does occur, it might be inconsequential over the long term because many seedlings get started after the second year (see bar graph, right). It also is known that when severely burned forests are left to naturally regenerate, successful, abundant conifer recruitment continues for years.

Another factor to consider for conifer regeneration is how a forest establishes structurally across time and space. This is particularly relevant if trees are planted, and especially if the goal is to resemble natural patterns of establishment. Various studies have inferred a wide variety of structural patterns in mature and old-growth Douglas-fir (Pseudotsuga menziesii) forests, including rapid and dense tree regeneration within about 10 years of fire to slow and sparse regeneration occurring over a period of 50 to 100 years after a fire (for example, Poage and others, 2009. ${ }^{1}$ ) Two of the most commonly speculated mechanisms behind variable establishment patterns involve variation in seed-source availability and the occurrence of shortinterval, repeated fires during early stages of forest succession.

For the studies summarized here, researchers assessed regeneration for as long as 19 years post-fire. That is a short amount of time in the life of most Pacific Northwest forests. They found that conifers continued regenerating 10-15 years after a fire, with the peak in successful regeneration occurring 4-6 years after the fire. In naturally regenerating areas, age and distribution patterns of young trees indicate a prolonged and variable period of natural establishment rather than a single pulse or fixed pattern. Several patterns of tree establishment in burned areas occurred, including rapid and immediate filling, delayed regeneration for 4-9 years followed by rapid filling, slow and constant filling, and extremely limited regeneration.

${ }^{1}$ Poage, N.J., Weisbert, P.J., Impara, P.C., Tappeiner, J.C., and Sensenig, T.S., 2009, Influences of climate, fire, and topography on contemporary age structure patterns of Douglas-fir at 205 old forest sites in western Oregon: Canadian Journal of Forest Research, v. 39, no. 8, p. $1518-1530$.
Speculating into the future, these patterns could result in large variations of tree densities and sizes across a landscape.

\section{Species Occurrence across the Landscape}

Forest structure describes patterns of tree species across the landscape, including altitudinal differences. In the KlamathSiskiyou Ecoregion, regeneration across areas dominated by white fir (Abies concolor) generally is greater than in areas dominated by Douglas-fir. Low-altitude sites experiencing high heat loads usually have low productivity, with an apparent

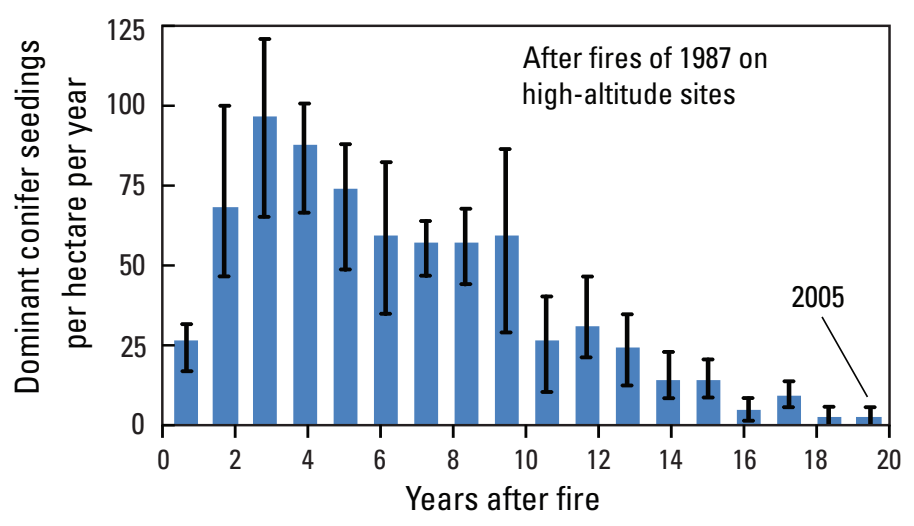

Dominant conifer abundance by year of establishment in the Klamath-Siskiyou Ecoregion, southern Oregon. Error bars indicate standard error.

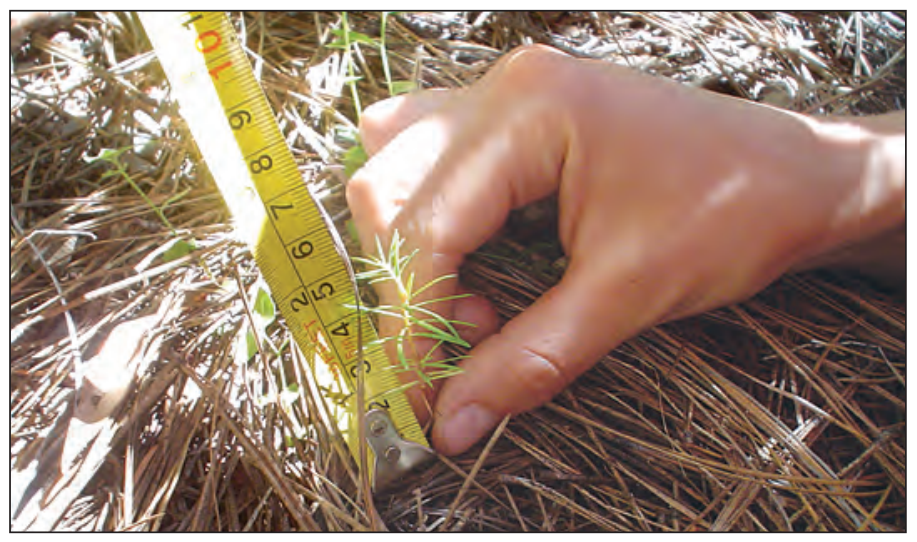

Naturally regenerating conifer seedling. Photograph by J.E. Halofsky, 2006.

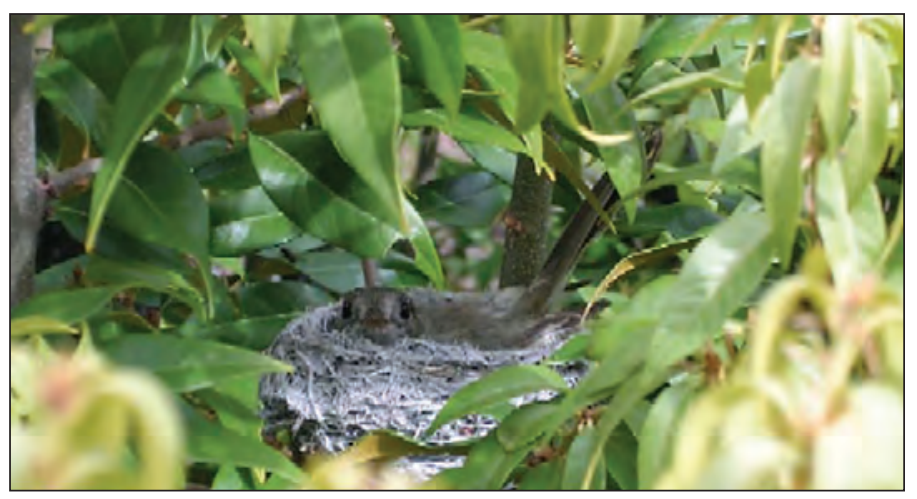

A variety of wildlife find habitat in the shrub revegetation after the Biscuit Fire, southern Oregon. Photograph by M. Donaghy Cannon, Oregon State University. 
threshold of major change near 800 meters. Below this altitude, Douglas-fir seedling growth is particularly slow. In contrast, Douglas-fir seedling growth is maximized at high-altitude sites that experience high heat loads, presumably because the growing season is extended or because available moisture is increased.

\section{Balance between Conifers and Shrubs}

A common assumption is that the survival and growth of conifer seedlings is limited by shrubs and hardwoods. This assumption can lead to management of shrubs, such as cutting or mechanical shredding, to decrease competition. Yet, the presence of shrubs and hardwoods sometimes benefits conifer regeneration. This is particularly apparent on southerly aspects where Douglas-fir and tanoak (Quercus) predominate. In this situation, a positive relationship exists between shrub cover and tree-seedling growth. In the higher altitude white fir forests, the relationship is negative-more shrub cover leads to lower seedling growth. In general, conifer growth seems to be much more sensitive to environmental conditions than to the effects of competing vegetation. Encroachment of vegetation in the lower canopy appears to be more influential on tree growth than competition from shrubs that overtop young conifers. For Douglas-fir in particular, some level of protection may even be afforded young trees that are overtopped or shaded by neighboring vegetation. This shrub cover also provides an important habitat for a variety of wildlife species in the ecoregion.

\section{The Case of Riparian Forests}

Effects of fire in upland forests are well studied compared to riparian forests, which occur along streams and differ in form and composition from upland forests. In areas like the Klamath-Siskiyou Ecoregion, understory fire severity tends to be lower in riparian areas compared to adjacent upland forests, whereas fire severity in the overstory is similar in these two types of forests. Patterns of riparian regeneration are influenced in large landscape contexts by factors associated with position in a watershed (headwater versus mainstem channels). At finer resolutions, ranging from meters to a few kilometers of stream length, other factors might influence patterns of regeneration, such as differences in vegetation composition before the fire, site conditions that may promote hardwood- versus coniferdominated plant communities, and understory fire severity.

\section{Management Implications}

- Many native plants in mixed-severity fire regimes have traits that make them resilient to fire.

- Management that incorporates natural disturbances, including short-interval severe fires, will likely perpetuate a diversity of habitats and pathways for forest development across the landscape.

- Natural regeneration generally takes longer to produce conifers than planting; however, it creates a more varied forest, which is likely to benefit wildlife.

- The removal of dead or dying large conifer trees after a fire, called salvage logging, may not make much difference to forest regeneration because successful and abundant conifer recruitment continues for years even after a severe fire.
- Shrubs can be beneficial to conifer regeneration on loweraltitude southerly aspects.

- Management can change the shrub composition of forest patches.

- Vegetation-control measures focusing on reducing interactions among Douglas-fir seedlings and surrounding vegetation may be most effective on mid- to high-altitude sites.

- Management practices that reduce upland fire severity also may reduce riparian fire severity.

- Regeneration of riparian forests may need to be tailored to site-specific conditions.

\section{Findings presented are based on these publications.}

Donato, D.C., Fontaine, J.B., Campbell, J.L., Robinson, W.D., Kauffman, J.B., and Law, B.E., 2006, Postwildfire logging hinders regeneration and increases fire risk: Science, v. 311, no. 5759, p. 352.

Donato, D.C., Fontaine, J.B., Robinson, W.D., Kauffman, J.B., and Law, B.E., 2008, Vegetation response to a short interval between high-severity wildfires in a mixed-evergreen forest: Journal of Ecology, v. 97, no. 1, p. 142-154.

Halofsky, J.E., and Hibbs, D.E., 2008, Determinants of riparian fire severity in two Oregon fires, USA: Canadian Journal of Forest Research, v. 38, no. 7, p. $1959-1973$.

Irvine, D.R., Hibbs, D.E., and Shatford, J.P.A., 2009, The relative importance of biotic and abiotic controls on young conifer growth after fire in the Klamath-Siskiyou Region: Northwest Science, v. 83, no. 4, p. 334-347.

Lopez, M.J., 2007, Plant community recovery after high severity wildfire and post-fire management in the Klamath Region: Corvallis, OR: Oregon State University, M.S. Thesis, 133 p.

Shatford, J.P.A., Hibbs, D.E., and Puettmann, K.J., 2007, Conifer regeneration after forest fire in the KlamathSiskiyous-How much, how soon?: Journal of Forestry, v. 105 , no. 3 , p. 139-146.

Thompson, J.R., Spies, T.A., and Ganio, L.M., 2007 , Reburn severity in managed and unmanaged vegetation in a large wildfire: Proceedings of the National Academy of Sciences, v. 104, no. 25, p. 10743-10748, accessed November 8, 2011, at http://www.pnas.org/ content/104/25/10743.full.

\section{For additional information, contact:}

Director, Forest and Rangeland Ecosystem Science Center U.S. Geological Survey

777 NW 9th Street

Corvallis, Oregon 97330

http://fresc.usgs.gov

Authors: David Hibbs, Oregon State University and Ruth Jacobs, USGS Design: Bill Gibbs

Publishing support provided by the U.S. Geological Survey

Publishing Network, Tacoma Publishing Center 